\title{
ELECTROPHORETIC AND IMMUNOLOGICAL CHARAC- TERIZATION OF SPECIFIC ANTIGENS INDUCING IMMUNE RESISTANCE DERIVED FROM CATTLE TICK BOOPHILUS ANNULATUS
}

\author{
Aggour, M.G. ${ }^{*}$ Ghattas, M.W. ${ }^{* *}$ and Badawy, G.A. ** \\ *Biotechnology Dept., Animal Health Research Institute Dokki. \\ ** Port-Said Lab, Animal Health Research Institute.
}

\begin{abstract}
SDS- PAGE analysis was carried out on salivary gland antigen (SGA) of the cattle tick Boophilus annulatus. A protein profile was observed with various polypeptide bands. On the other hand,has been determined the presence of the specific antigen on salivary gland extract by means of immunoblotting analysis using hyperimmune serum of rabbit inoculated with extract. Higher reactivity was observed at three polypeptides (48,42 and $32 \mathrm{KD}$ ).
\end{abstract}

\section{INTRODUCTION}

The Acquisition of immunity in cattle to tick infestation was first described by Johnson and Bancroft (1918). Trager (1939) described a similar phenomenon in rabbits infested with Dermacenter variabilis. Attempts have been made to determine the bases of antitick immunity (Riek 1962, Allen et. al. 1977, Allen and Humphreys 1979, Askenase 1980, Brown et. al. 1982, Kemp et. al. 1986 and Mongi et. al. 1986).

Several workers induced resistance to ticks using salivary glands: Hyalomma anatolicum (Kohler et. al. 1967 ), Ripicephalus sanguinen (Garin and Grabarev ; 1972 ), Dermacenter andersoni in guinea pigs and cattle (Allen and Humphreys, 1979)and Ammblyomma americanum in guinea pigs (Brown, et al., 1984). The immunogenicity of the salivary 
gland was demonstrated firstly by Allen and Humphreys (1979) and according to Brown et. al. (1984) and Brown and Askenase (1986 a, b) the antigens responsible for the induction of host resistance appear to be of salivary gland origin.

\section{MATERIALS AND METHODS}

Ticks: About 2000 adult ticks(Boophilus annulatus)were collected from naturally infested cows from different investigated farms and identified according to Hoogstraal(1956).Ticks were kept in a biological incubator at constant temperature $28{ }^{\circ} \mathrm{C}$ and $75 \%$ relative humidity.

Preparation of salivary gland antigens (SGA): Salivary glands were obtained from 1000 adult male and female B.annulatus after feeding for 4 to 5 days on rabbits as described by Martinod et. al. (1985). The salivary glands were harvested in $2 \mathrm{ml}$ phosphate buffered saline (PBS) without protease inhibitors. The glands were sonicated at amplitude of 22 $(\mathrm{Mm})$ for 2 minutes at $4 \mathrm{C}$. The sonication process was repeated four times at 3 minutes intervals. A soluble fraction of the extract was obtained after centrifugation at $1000 \mathrm{xg}$ for 15 minutes. The protein content in the soluble fraction was determined by the method of Lowry et. al. (1951).

Preparation of hyperimmune serum: Three successive injections with SGA in a group of 5 Boscat rabbits was performed. One week after the completion of the $2^{\text {nd }}$ and one week after completion of the $3^{\text {rd }}$ injection, blood was collected from the central ear vein of each rabbit and allowed to clot at room temperature for 1 hour. After incubation overnight at $4{ }^{\circ} \mathrm{C}$, serum was collected by centrifugation and stored at $-20{ }^{\circ} \mathrm{C}$ until use.

Detection of specific antigens in salivary glands by the western blot technique. Antiserum to SGA was used to detect tick antigens in the SGA extracts. The extract was analyzed on 5 to $15 \%$ polyacrylamide gradient gel in the presence of sodium dodecyl sulfate (SDS - PAGE) by the method of Laemneli and Favre (1973). The separated proteins were electrophoretically transferred into nitrocellulose membrane as described 
by Burnette (1981). Non - specific reactive sites on the nitrocellulose paper were blocked by $5 \%$ fat - free milk in Tris - buffered saline (TBS) for 2.5 hours at room temperature $25{ }^{\circ} \mathrm{C}$. Strips were incubated with the respective primary antisera diluted 1:400 for 4 hours at room temperature under constant shaking. After a series of washing in 5\% fat - free milk in TBS containing goat - antirabbit IgG horseradish peroxidase (HRP) conjugate(SIGMA - ALDRICH)diluted 1:1000.The strips were incubated for 2 hours in the conjugate at room temperature with constant shaking. The conjugate was decanted and the strips were washed in several changes of TBS. Finally, the strips were developed in 4 chloro -1naphthol in methanol at room temperature.

\section{RESULTS}

Separation on SDS-PAGE and identification by the western Blotting technique of the different polpeptides detectable on SGA by the antiserum revealed the presence of many polypeptides. Polypeptides recognized by antiserum to SGA ranged in molecular weight from 18.5 to 85.0 KD. Three polypeptides $(48,42$ and $32 \mathrm{KD})$ were the most prominent (Fig.1 and Table.1).

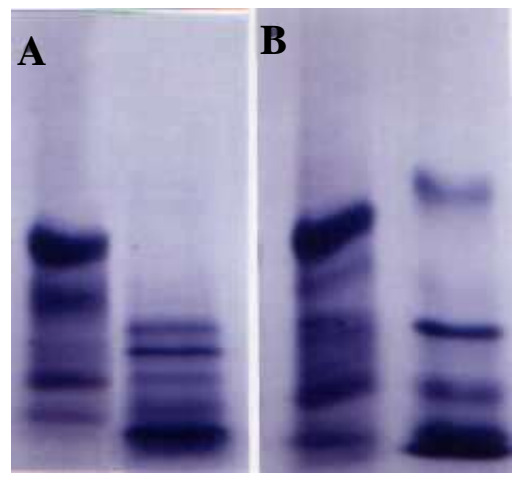

Fig(1): A) SDS - PAGE of antigen purified from salivary glands of Boophilus annulatus .

B) Immunoblotting analysis of antigen purified from salivary glands of Boophilus annulatus. 
Lane (1): Molecular weight marker.

Lane (2): Salivary gland antigen of B.annulatus.

Table : 1

\begin{tabular}{|c||c|}
\hline Band & Molecular weight marker ( KD ) \\
\hline \hline 1 & 97.4 \\
2 & 66 \\
3 & 45 \\
4 & 36 \\
5 & 19 \\
6 & 14 \\
\hline
\end{tabular}

\section{DISCUSSION}

In a study on Ripicephalus. appendiculatus, Fawcett et. al. (1986) showed an enormous increase in types 11 and 111 alveoli in the course of feeding. The cells became enlarged and the alveolar lumenae diluted filling with salivary secretions. In a related study on Amblyomma .americanum, Shelby et. al. (1987) showed biochemical differentiation in the course of feeding of this tick. In an earlier study, McSwain et. al. (1982) showed the synthesis of a new polypeptides in A. americanus and a 25 fold increase in the size of cells and protein content.

Gill et. al. (1986) showed in Hyalomma anatolicum (Koch) that several polypeptides found in native ticks increase in quantity with feeding.

Brown et. al. $(1982,1984)$ identified in the salivary glands of the three - host tick $A$. americanum a 25 -kd polypeptide that they considered to be responsible for the induction of antitick immunity in guinea pigs. In a study using Dermacenter andersoni Stiles SGA and tick resistant rabbit serum, Gordan and Allen (1987) identified several polypeptides ranging from 18 to $172 \mathrm{KD}$. The polypeptide of $172 \mathrm{Kd}$ was considered immunodominant in the SGA preparations. Shapiro et. al. (1987) reported that $R$. $\overline{\text { Kafr El-Sheikh Vet. Med. J. Vol. } 2 \text { No. } 2 \text { (2004) }}$ 
appedicculatus SGA contained a 90 - KD polypeptide and considered it responsible for the induction of antitick resistance in rabbits.

Our study has identified a common polypeptide in SGA responsible for the elicitation of antitick immunity where three distinct polypeptide bands were prominent at 48,42 and $32 \mathrm{KD}$. This disparity may reflects difference in experimental approach.

Recently, Willadsen (1987) speculated on different immunological approaches to the control of ticks and pointed out that mechanisms in tick resistance arising from infestations are different from those generated by vaccination with tick antigens. The most important difference was that tick resistance as a result of infestation is affected by immediate hypersensitivity reactions; whereas antibody mediated responses are responsible for immunity after vaccination. The latter responses were shown to cause gross damage to $B$. microplus ticks feeding on cattle immunized with tick derived antigens (Agbede and Kemp 1986).

\section{REFERENCES}

- Allen, J. R. and Humphreys, S. J. (1979): Immunization of guinea pigs and cattle against ticks. Nature 280: 491 - 493.

- Allen, J.R.., Doube, B.M. and Kemp, D.H. (1977): Histology of bovine skin reactions to Ixodes holocyclus Neumann. Can. J. Comp. Med. 41: 26 - 35.

- Agbede, R.S. and Kemp.D.H.(1986): Immunization of cattle against Boophilus microplus using extracts derived from adult female ticks: histopathology of tick, feeding on vaccinated cattle. Int. J. Parasitol. 16: 35 - 41.

- Askenase, P. W. (1980): Immunopathology of parasitic diseases: invo-lvement of basophiles and mast cells. Springer Semin. Immunopathol. 2: 417 - 442.

- Brown, S. J. and Askenase, P.W. (1986a): Characterization of Amblyomma americanum derived salivary gland proteins responsible for the elicitation of host immunity . Morphology, 
Physiology and Behavioral Biology of Ticks pp. 300 - 328 Horwood, Chichester.

- Brown, S.J. and Askenas, P.W. (1986b): Amblyomma americanum : physiochemical isolation of protein derived from the tick salivary gland that in capable of inducing immune resistance in guinea pigs. Experimental Parasitology, 62: 40 50 .

- Brown, S. J., Graziano, F. M. and Askenase, P. W. (1982): Immune serum transfer of cutaneous basophil - associated ressistance to ticks mediated by $7 \mathrm{SIgG1}$ antibodies. J. Immunol. 129: 2407- 2412.

- Brown, S. J., Shapiro, S.Z. and Askenase, P. W. (1984): Characteri-zation of tick antigens inducing host immune resistance.1.Immunization of guinea pigs with Amblyomma americanum - derived salivary gland extracts and identification of an important salivary protein antigen with guinea pig antitick antibodies. J. Immunol. 133: 3319 - 3325.

- Burnette, W. N. (1981): "Western blotting" Electrophoretic transfer of proteins from sodium dodecyl sulfate polyacrylamide gels to unmodified nitrocellulose and radiographic detection with antibody and radioiodinated protein. A. Analytic. Biochem. 112: 195 - 203.

- Fawcett, D.W.; Binnington, K. and Voigt, W.P.(1986): The cell biology of ixodid tick salivary gland, pp. 22 - 45. In J.R. Sauer and J.A. Hair (eds.), Morphology, physiology and behavioral biology of ticks. Ellis Horwood, Chichester, England .

- Garin, N.S. and Grabarev, P.V.(1972): Protective reaction in rabbits and guinea pigs to repeated feeding by Rhipicephalus 
sanguineus Latreille, 1806. Meditsinskaya Parazitologiya, Parazitarnye Bolenzmi, 46 (3): 274-277.

- Gill, H.S., Boid, R. and Ross, C.A. (1986): Isolation and characteriz-ation of salivary antigens from Hyalomma anatolicum. Parasitol. Immunol. 8: 11 - 25.

- Gordan, J. R. and Allen, J. R. (1987): Isolation and characterization of salivary antigens from the female tick, Dermacenter andersoni. Parasitol. Immunol. 9: 337 - 352.

- Hoogstraal, H. (1956): African Ixodidea. Ticks of the Sudan (with special reference to equatorial province and with preliminary reviews of the genera Boophilus,Margaropus, and Hyalomma). Vol.1 Research report NM005 050. 29 - 70.

- Johnson, T. H. and Bancroft, M. J. (1918): Tick resistant condition in cattle. Proc. R. Soc. Qyeensl. $30: 219$.

- Kemp, D. H., Agbedf, R. I. S., Johnston, L. A. Y. and Gough, J. M. (1986): Immunization of cattle against Boophilus microplus using extracts derived from adult female ticks feeding and survival of the parasite on vaccinated cattle. Int, J. Parasitrol. 16: 115 - 120.

- Kohler, G.; Hoffman, F.and Weiland, G. (1967): Immunobiologische Untersuchungen an kanichen nit ixodninfestationen. Berliner Munc-hener Tieraerzil Wochenschift, 80: 396 - 400 .

- Laemneli,U.K.and Favre.M.(1973): Maturation of the bacteriophage T4. J. Molec. Biol. 80: 575 - 591.

- Lowry, O. H., Rosebrough, M. J., Farr, A. L. and Randall, R. $J$. (1951): Protein measurement with the follin phenol reagent. J. Biol. Chem. 193: 265 - 275. 
- Martinod, S., Brossard, M. and Moreau, Y. (1985): Immunity of dogs against B.canis, its vector Dermacenter reticulates and Ixodes ricinus in endemic areas. J. Parasitol. 71: 269 - 273.

- McSwain, J. L., Essenberg, R. C. and Sauer, R. R. (1982): Protein changes in the salivary glands of the female lone star tick,Amblyomma amereicanum, during feeding. J.Parasitol. 68:100-106.

- Mongi, A.O., Shapiro, S.Z. and Cunningham, M.P. (1986): Immu-nization of rabbits with R.appendiculatus antigenantibody complexes. Insect Sci. Applic. 7: 381 - 404.

- Riek, R. F. (1962): Studies on the reactions of animals to infestation with the tick Boophilus microplus (Canestrini). Aust. J. Agric. Res. 13: 532 - 550.

- Shapiro,S. Z.,Buscher,G.and Dobbelaere, D.A.E. (1987): Acquired resistance to Rhipicephalus appendiculatus (Acari : Ixodidae): Identif-ication of an antigen eliciting resistance in rabbits . J.Med. Entemol. 24: 147 - 154.

- Shelby, K.S.; Bantle, J.A. and Sauer, J.R. (1987):

Biochemical differentiation of lone star tick, Amblyomma americanum(L.), salivary gland: effects of attachement feeding and mating. Insect Biochem. 17: 883 - 890.

- Trager,W.(1939): Acquired immunity to ticks .J. Parasitol. 25: 57-81.

- Willadsen, P. (1987): Immunological approach to the control of ticks. Int. J. Parasitol. 17: 671- 677.

التحليل الكهربي و الصفة المناعية لتحديد الانتيجين المناعي للغدد اللعابية الخاصة بقر اد الأبقار نوع بوفيلس انيولاتين الاتين 
محمد جلال عجور * - ممدوح وجدي غطاس*** - غريب عبد العزيز بدوي

$$
\text { "معهر بحوث صحة الحيوان - الاقى }
$$

* معهد بحوث صحة الحيوان - المعمل الفرعي بمحمية الجميل الطبيعية ببورسعيد

تم استخدام اختبار الاستقطاب الكهربي للتحليل الانتيجينى لمستخلص الغدد اللعابية لقراد الأبقار نوع بوفيلس انيولاتس0 وقد أظهرت النتائج وجود أكثر من نوع لعديد البيبتيد وبأجراء اختبار الطبع المناعي لهذه الانتيجينات ضد المصل عالي المناعة المحتوى على مضادات تلاك الانتيجينات ، أظهر مستخلص الغدد اللعابية تفاعلات مناعية متخصصة ـ وكان أعلى تفاعل مناعي عند عديد البيبتيد كان وزن الجزئي عند 48 ، 42 ، 32 كيلودالنون. 